\title{
Food fuelled with fungi
}

\section{Ecologists are starting to appreciate the power of microbes to make crops hardier.}

\section{BY NICOLA JONES}

$\mathrm{W}$ ith the planet's population booming and climate change threatening traditional 'bread-basket' regions, researchers are seeking ways to squeeze more food from the land. Some are taking a sideways approach: instead of trying to produce hardier crops through breeding or genetic modification, they are manipulating the vast array of symbiotic microorganisms that live in plants.

Next spring, Adaptive Symbiotic Technologies in Seattle, Washington, will bring to market the first commercial product that harnesses such microorganisms - known as endophytes - to improve crops. The company plans to sell a mixture of fungi for coating rice and maize (corn) seeds, which it says will produce crops with high yields and reduced water use even in harsh conditions. "It's a real paradigm shift in plant ecology," says company founder and plant biologist Rusty Rodriguez. "Up till now we have focused on plants as individuals, as we have with animals."

In the same way that biologists are now starting to understand the power and influence of the trillions of microbes living in and on the human body, ecologists are getting to grips with plant microbiomes. The result is powerful. Instead of having to find and introduce into a crop a single gene for a coveted trait such as salt tolerance, researchers can use a slew of interacting genes that comes pre-integrated in a living organism, such as a symbiotic fungus.

Conventional breeding has helped to create varieties with increased tolerance to drought, but progress in introducing new genes through genetic manipulation has been slow. Despite decades of research, only one drought-tolerant genetically modified crop has been approved in the United States: Monsanto's DroughtGard maize, which expresses a stress-response gene from bacteria.

Although symbiotic plant-microbe relationships - such as those of the nitrogen-fixing bacteria that live in the roots of legumes have been known for many decades, applied research in this field is relatively recent. Only in the 1970s did researchers realize that a fungus living in symbiosis with tall fescue grass was responsible for making cattle grazing on infected pastures ill. Scientists in New Zealand later discovered that some endophyte-ridden grasses, although poisonous to livestock, were resistant to attack by weevils. This spawned a niche industry that develops and markets endophyte-hosting turf varieties that repel pest attacks without being toxic to animals.

Now some researchers are applying similar philosophies to food crops. The approach bucks a trend of sterilizing and simplifying crops, says Rodriguez. "Agriculture has spent the past century wiping out the microbes living in our plants, through pesticides and fertilizers. Now we're trying to reverse that."

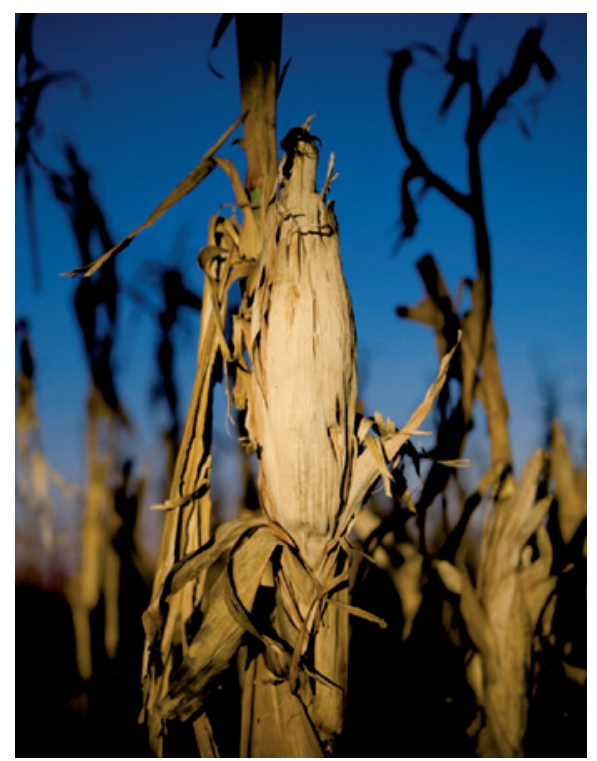

Maize could survive drought with the help of fungi.

Endophyte researcher James White at Rutgers University in New Brunswick, New Jersey, agrees. "A lot of companies don't think this way - they go for chemical control. They think the microbes get in the way," he says. "It's not the paradigm that these microbes are significantly impacting plants. But they are." There are thought to be millions of endophytic microbes in the world; only a fraction have been identified, and any given plant can host hundreds.

Rodriguez's work began by happy accident. In the early 2000s, while studying the dozen or so plant species that can survive at $50^{\circ} \mathrm{C}$ in the hot soils near geothermal vents in Yellowstone National Park in Wyoming, he found that all of them carried a symbiotic fungus. Although neither the plants nor the fungi could tolerate soil temperatures of $40^{\circ} \mathrm{C}$ by themselves, together they could (R. S. Redman et al. Science 298, 1581; 2002).

Rodriguez and his colleagues later discovered that the fungi were easily transferable: they could grow in anything from watermelons to maize and confer heat- and droughttolerance on those crops. "The endophytes somehow protect the plants from oxidation, so the plants don't turn up all their stress defences," says Rodriguez.

Those findings led him to look for other endophytes optimized to tackle the problems likely to be caused to particular food crops by climate change (R. S. Redman et al. PLoS ONE 6, e14823; 2011). The result is a commercial mix of about half a dozen fungi that the team named BioEnsure. Field tests done or commissioned by the company show that, compared to untreated seeds, the product increased maize yields by $85 \%$ in Michigan during a 2012 drought, increased seed germination rates by two to five times during $5{ }^{\circ} \mathrm{C}$ cold snaps, and enabled maize to use one-third less water. In rice, the scientists saw yield increases of 3-6\% in 2012 and 2013, despite drought and early-season planting when temperatures were cool. The crop also used $25-50 \%$ less water than normal.

BioEnsure has been approved for use by the US Food and Drug Administration and the Department of Agriculture, and independent tests have shown the mixture to be non-toxic. Rodriguez plans eventually to produce targeted endophyte mixes for more crops, including soya beans, wheat, barley and sugar cane.

But the question of whether BioEnsure will work in commercial conditions is hard to answer: although Adaptive Symbiotic Technologies' field-test results are public, they have not been peer reviewed. Richard Richards, who leads research to breed better wheat for the Australian Commonwealth Scientific and Industrial Research Organisation's plant industry division in Canberra, is dubious. "Typically, there is a metabolic cost of hosting an endophyte, so that crops with endophytes are likely to grow less and be less productive," he says. Rodriguez counters that "in all the field work we've done over 15 years we haven't seen anything suggesting metabolic cost".

Others are cautiously optimistic. Mogens Nicolaisen, who works with plant pathogens at Aarhus University in Denmark, thinks that endophytes could be a good way to help introduce resistance to both drought and disease, including pathogens such as wheat rust, an area that Rodriguez says he is pursuing. But, Nicolaisen adds, getting the endophytes into seeds and regulating their growth in different environmental conditions will be tricky. "It will be very hard to control," he says. 